\title{
Evaluation of infants with HIV-infected mothers and perinatal transmission in Turkey: A single-center experience
}

\author{
(D) Nurhayat Yakut, (D) Eda Kepenekli \\ Division of Pediatric Infectious Diseases, Department of Pediatrics, Marmara University Faculty of Medicine, Istanbul, Turkey
}

\begin{abstract}
OBJECTIVE: The most common route of HIV infection in children is through perinatal transmission. In this study, we aimed to evaluate the characteristics of infants with HIV-infected mothers and perinatal HIV transmission.

METHODS: We conducted a retrospective, single-center study of HIV-exposed infants in between December 2017 and October 2019 in a Marmara University Pendik Training and Research Hospital.

RESULTS: A total of 18 infants were examined. All babies were born by cesarean section, and none of them were breastfed. Seventeen mothers were diagnosed with HIV before pregnancy. These mothers had received antiretroviral therapy (ART) during pregnancy, and their viral loads before delivery were negative. An antiretroviral prophylaxis with oral zidovudine was started in all infants within their $1^{\text {st }}$ day of birth and continued for at least 6 weeks. All infants were tested for their HIV viral load within the first $48 \mathrm{~h}$ of birth, with negative results, and 12 infants were tested for anti-HIV antibodies at the $18^{\text {th }}$ month, again with negative results. In this study, we determined that none of the infants had been infected with HIV.

CONCLUSION: Our findings highlight the importance of initiating ART for all HIV-infected pregnant women and the importance of protection modalities during pregnancy, delivery, and the postnatal period for the prevention of perinatal transmission of HIV.
\end{abstract}

Keywords: Children; HIV; infection; perinatal transmission; Turkey.

Cite this article as: Yakut N, Kepenekli E. Evaluation of infants with HIV-infected mothers and perinatal transmission in Turkey: A singlecenter experience. North Clin Istanb 2021;8(3):243-248.

A ccording to data from the Joint United Nations Program on HIV/AIDS (UNAIDS), 36.7 million people worldwide are infected with HIV and 1.8 million are newly diagnosed [1]. The first AIDS case was reported in Turkey in 1985. The Turkish Ministry of Health reports that in Turkey, there are 21,988 patients with a diagnosis of HIV or AIDS and that 718 of these people are children or adolescents [2]. Perinatal transmission, also known as vertical or motherto-child transmission, is the main route of HIV infection in children. It is estimated that there are 2 million children living with HIV infection worldwide [3]. Pediatric HIV infection can occur during pregnancy, delivery, or breastfeeding. The rate of transmission without intervention ranges from $15 \%$ to $35 \%[4,5]$. However, perinatal transmission of HIV can be prevented by taking precautions in the perinatal period, and the probability of transmission can be reduced to below $2 \%$ with plasma HIV viral load suppression $[6,7]$. Prevention of perinatal transmission of HIV is possible using the following measures: Antiretroviral therapy (ART) throughout the pregnancy, cesarean

Received: January 14, 2021 Accepted: February 09, 2021 Online: May 24, 2021

Correspondence: Nurhayat YAKUT, MD. Marmara Universitesi Tip Fakultesi, Cocuk Sagligi ve Hastaliklari Anabilim Dali, Cocuk Enfeksiyon Hastaliklari Klinigi, Istanbul, Turkey. 
section birth at the $39^{\text {th }}$ week, administration of an antiretroviral prophylaxis to the newborn, physician care, and elimination of breastfeeding. This study aimed to evaluate the characteristics of infants with HIV-infected mothers and perinatal transmission at a tertiary care hospital in Turkey.

\section{MATERIALS AND METHODS}

\section{Study Design and Data Collection}

This retrospective single-center study examined 18 infants with $\mathrm{HIV}$-infected mothers at a pediatric infectious disease outpatient clinic in a tertiary care hospital in Turkey. The medical records were collected from patients who attended our hospital between December 2017 and October 2019. The following demographic and laboratory data were collected retrospectively: Gender; birth weight; gestational age; type of delivery; obstetric history (gravida or parity); maternal follow-up period and ART regimen; antiretroviral (ARV) prophylaxis; laboratory results including leukocyte, lymphocyte, platelet counts, and hemoglobin level within $48 \mathrm{~h}$ and after administration of the ARV prophylaxis; HIV RNA levels within the first $48 \mathrm{~h}$, at postnatal $2^{\text {nd }}$ week, $4^{\text {th }}$ week, $4^{\text {th }}$ month, and $6^{\text {th }}$ month; and the presence of HIV antibodies at the $12^{\text {th }}$ month and the $18^{\text {th }}$ month.

\section{Statistical Analysis}

Data were entered into Microsoft Office Excel 2010 (Microsoft; Redmond, WA, USA). The statistical analysis was performed using SPSS version 21.0 (SPSS Inc.; Chicago, IL, USA). Mean, median, minimum, and maximum values were used for continuous variables. Frequencies and percentages were used to summarize categorical data.

\section{Ethical Approval}

The Clinical Research Ethics Committee of Marmara University Faculty of Medicine approved this study (Date: 04.09.2020 and Decision no: 09.2020.945).

\section{RESULTS}

A total of 18 infants and their HIV-infected mothers were examined during the study period. There were 7 (39\%) female and 11 (61\%) male infants. The median and mean birth weight were $3045 \mathrm{~g}$ and $3011.39 \pm 674.726$ (range 1700-4320) g, respectively. None of the infants

\section{Highlight key points}

- HIV perinatal transmission is an important cause of children mortality worldwide. In this study, none of the infants haven't become infected with HIV.

- The number of cases with HIV infection is increasing in Turkey.

- $\quad$ There are a little data about HIV exposed infants and perinatal transmission in Turkey.

- Antiretroviral therapy for mothers and prevention modalities is important to reduce, even eliminate perinatal HIV transmission.

breastfed. There were two preterm, and two low birth weight infants in our study sample. All infants were given ARV prophylaxis with oral zidovudine (ZDV) for at least 6 weeks. The dosage of ZDV was determined according to gestational age. ZDV was started $4 \mathrm{mg} /$ $\mathrm{kg}$ twice daily except two preterm infants. The demographic characteristics of the infants and mothers are summarized in Table 1. Seventeen mothers had been diagnosed with HIV before pregnancy and received ART during pregnancy. One mother delivered at the another center has received intrapartum prophylaxis with intravenous (IV) ZDV. The ART regimen of mothers is shown in Table 2 .

HIV RNA analysis for the infants was performed within the first $48 \mathrm{~h}$ of birth, at postnatal $2^{\text {nd }}$ week, $4^{\text {th }}$ week, $4^{\text {th }}$ month, and $6^{\text {th }}$ month. There were 18 infants available for testing within the first $48 \mathrm{~h}, 14$ infants at the postnatal $2^{\text {nd }}$ week, 15 infants at the $4^{\text {th }}$ week, 17 infants at the $4^{\text {th }}$ month, and 15 infants at the $6^{\text {th }}$ month. All results came back negative. Anti-HIV analysis was performed at the $12^{\text {th }}$ month and the $18^{\text {th }}$ month. There were 12 infants tested for anti-HIV antibodies at the $18^{\text {th }}$ month with all results found to be negative. HIV RNA analysis before delivery produced negative results in 17 mothers who received ART during pregnancy. The mean white blood cell (WBC) and lymphocyte counts within the first $48 \mathrm{~h}$ were $12911.11 \pm 3059.39$ (range, $8200-20300) / \mathrm{mm}^{3}$ and $6038.89 \pm 1891.19$ (range, 2800-10200)/ $\mathrm{mm}^{3}$, respectively. The mean WBC and lymphocyte counts at the $6^{\text {th }}$ week were $10433.33 \pm 2758.51$ (range, 5700-16000)/ $\mathrm{mm}^{3}$ and $6700 \pm 2574.99$ (range, 2500-12000)/ $\mathrm{mm}^{3}$, respectively. The laboratory findings of the infants are summarized in Table 3. No adverse effects related to ZDV were observed in any of the infants. All infants tested negative for HIV at their last follow-up. 
TABLE 1. The demographic characteristics of the infants and mothers

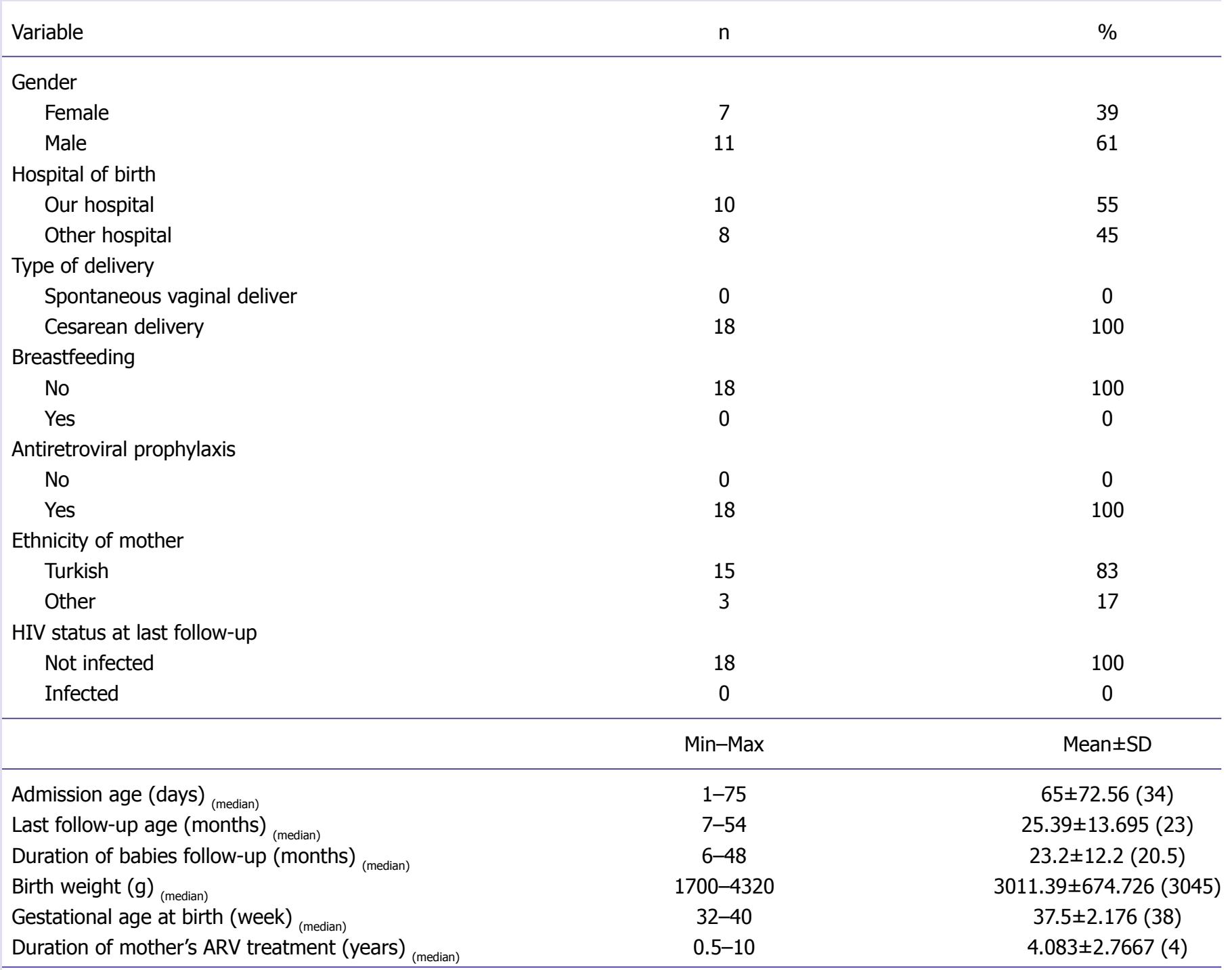

HIV: Human immunodeficiency virus; ARV: Antiretroviral; Min: Minimum; Max: Maximum; SD: Standard deviation.

\section{DISCUSSION}

Although the number of new HIV infections, as well as perinatal infections, has fallen in the United States, perinatal transmission is one of the most important challenges facing developing countries in the HIV epidemic $[8,9]$. The majority of children with HIV have acquired it through perinatal transmission, during pregnancy, at childbirth, or from breastfeeding [10]. Therefore, the prevention modalities of ART during pregnancy and delivery, cesarean delivery, and postnatal ARV prophylaxis for the infant are the keys to reducing new HIV infection in children $[11,12]$. In Turkey,

\section{TABLE2. Antiretroviral therapy regimen of mothers}

\begin{tabular}{lc} 
Drugs & $\%$ \\
\hline Emtricitabine/tenofovir+raltegravir & 41 \\
Emtricitabine/tenofovir+lopinavir/ritonavir & 35 \\
Elvitegravir/cobicistat/emtricitabine/tenofovir & 23.5 \\
Zidovudine/lamivudine+lopinavir/ritonavir & 0.5
\end{tabular}

limited studies have evaluated the perinatal transmission of HIV and infection outcomes $[13,14]$. In this 
TABLE 3. The laboratory findings of the infants with HIV-infected mothers

\begin{tabular}{lcc} 
Variables & Min-Max & Mean \pm SD \\
\hline Hemoglobin [in the first $48 \mathrm{~h}, \mathrm{~g} / \mathrm{dl}$ (median)] & $10.4-19.3$ & $14.48 \pm 1.74$ \\
WBC [in the first $48 \mathrm{~h}, / \mathrm{mm}^{3}$ (median)] & $8200-20.300$ & $12911.11 \pm 3059.39$ \\
Thrombocytes [in the first $48 \mathrm{~h} / \mathrm{mm}$ (median)] & $16.000-496.000$ & $302,611.11 \pm 71,229.65$ \\
Lymphocytes [in the first $48 \mathrm{~h} / \mathrm{mm}^{3}$ (median)] & $2800-10.200$ & $6038.89 \pm 1891.19$ \\
Hemoglobin [at the $6^{\text {th }}$ week, $\mathrm{g} / \mathrm{dl}$ (median)] & $8.2-13.4$ & $11.01 \pm 1.50$ \\
WBC [at the $6^{\text {th }}$ week, $/ \mathrm{mm}^{3}$ (median)] & $5700-16.000$ & $10433.33 \pm 2758.51$ \\
Thrombocytes [at the $6^{\text {th }}$ week, $/ \mathrm{mm}$ (median)] & $210.000-583.000$ & $445,944.44 \pm 116,695.44$ \\
Lymphocytes [at the $6^{\text {th }}$ week, $/ \mathrm{mm}^{3}$ (median)] & $2500-12.000$ & $6700 \pm 2574.99$ \\
Granulocytes [at the $6^{\text {th }}$ week, $/ \mathrm{mm}^{3}$ (median)] & $1700-3600$ & $2244.4 \pm 835.40$ \\
\hline
\end{tabular}

SD: Standard deviation; Min: Minimum; Max: Maximum; WBC: White blood cell.

study, we examined the characteristics of infants with HIV-infected mothers and perinatal transmission at a tertiary care hospital in Turkey.

As reported by the Turkish Ministry of Health in 2019, the rate of perinatal transmission was $0.47 \%$ $(\mathrm{n}=18)$ from January 2018 to December 2018 [2]. A study by Gülümser and Erbaydar investigated epidemiologic characteristics for HIV/AIDS in Turkey between 1985 and 2013 and reported that the rate of perinatal transmission has increased proportionally over time with $0.37 \%$ increase in the past 2 -year period [15]. In two studies conducted in our country, Sutcu et al. [13] and Inkaya et al. [14] demonstrated that the rate of perinatal transmission was $6.2 \%$ and $8.3 \%$, respectively. In this study, we did not observe any cases of perinatal transmission over the period of the study. Worldwide, developing countries with a high prevalence of HIV infection have developed policies, prevention modalities, and created follow-up organizations to reduce the incidence of perinatal transmission. Despite the efficacious interventions and the significant reduction of perinatal transmission of HIV in many of these countries, it continues to be a problem. In contrast, studies conducted in developed countries report a low perinatal transmission rate of $1.2-1.4 \%$ [16-18]. Furthermore, the rate of transmission is increasing in developing countries. In large cohort studies with HIV-exposed infants, the rate of perinatal transmission was reported to be $7.8 \%$ by Potty et al., $8.2 \%$ by Okoko et al., $5.9 \%$ by Read et al., and $8.9 \%$ by Mintsa-Ndong et al. [19-22]. One of the most important interventions for avoiding perinatal transmission of HIV is ART for all HIV-positive preg- nant women [23]. Many previous studies have shown that ART is effective in reducing the risk of perinatal transmission of HIV [24-27]. A cross-sectional survey study of HIV-exposed infants demonstrated that ART used during their mothers' pregnancy was associated with a low perinatal transmission rate of $1.58 \%$ [26]. In the present study, almost all the mothers (94.5\%) received ART during pregnancy. In addition, all infants in our study sample were given an ARV prophylaxis with oral ZDV for at least 6 weeks following birth as giving an ARV prophylaxis to the newborn immediately after birth reduces the risk of perinatal HIV transmission. The protection afforded by the prophylaxis against the virus is due to its access to the infant's bloodstream and the unintegrated virus that helps to prevent perinatal transmission $[28,29]$. In a cross-sectional study conducted on HIV-exposed infants, Yitayew et al. [30] reported that ARV drugs given to the mother during pregnancy and the administration of an ARV prophylaxis to the infant was the two most significant factors in avoiding perinatal HIV transmission. In a systematic review, Lumaca et al. [31] reported that an optimal ART regimen and the use of intrapartum $\mathrm{ZDV}$ for pregnant women are recommended to reduce perinatal HIV transmission. One mother in this study who gave birth at another hospital received an intrapartum prophylaxis with IV ZDV.

The other important preventive methods against perinatal HIV transmission are elective cesarean section and not breastfeeding if safety formula feeding can be accessed [32]. In this study, all infants were born by cesarean section, and none of them were breastfed. 
The important limitations of this study were its retrospective, single-center design, and small sample size.

\section{Conclusion}

It is possible to reduce, even eliminate, perinatal HIV transmission with preventive modalities. In this study, we determined that none of the infants in the study became infected with HIV during the study period. Our results reaffirm the benefits of ART for mothers, ARV prophylaxis for infants, birth by cesarean section, and avoidance of breastfeeding. Further multicenter studies with a larger number of patients are needed to provide more reliable results.

Ethics Committee Approval: The Marmara University Clinical Research Ethics Committee granted approval for this study (date: 04.09.2020, number: 09.2020.945).

Conflict of Interest: No conflict of interest was declared by the authors.

Financial Disclosure: The authors declared that this study has received no financial support.

Authorship Contributions: Concept - NY, EK; Design - NY, EK; Supervision - EK; Materials - NY, EK; Data collection and/or processing - NY; Analysis and/or interpretation - NY, EK; Literature review - NY, EK; Writing - NY, EK; Critical review - EK.

\section{REFERENCES}

1. Joint United Nations Programme on HIV/AIDS (UNAIDS). (2017). UNAIDS data 2017. Available at: https://www.unaids.org/sites/ default/files/media_asset/20170720_Data_book_2017_en.pdf. Accessed Apr 21, 2021.

2. T.C. Sağlık Bakanlığı Halk Sağlığı Genel Müdürlüğü Bulaşıcı Hastalıklar Dairesi Başkanlığı. HIV-AIDS İstatistikleri. Available at: https://hsgm.saglik.gov.tr/tr/bulasici-hastaliklar/hiv-aids/hiv-aidsliste/hiv-aids-istatislik.html. Accessed Apr 21, 2021.

3. Volmink J, Marais B. HIV: mother-to-child transmission. BMJ Clin Evid 2008;2008:0909.

4. World Health Organization, Unicef. Guidance on global scale-up of the prevention of mother to child transmission of HIV: towards universal access for women, infants and young children and eliminating HIV and AIDS among children / Inter-Agency Task Team on Prevention of HIV Infection in Pregnant Women, Mothers and their Children. WHO, 2007, Switzerland. Available at: https://www.who.int/hiv/ pub/toolkits/PMTCT9789241596015_eng.pdf. Accessed Apr 21, 2021.

5. Campos Coelho AV, Campos Coelho HF, Arraes LC, Crovella S. HIV1 mother-to-child transmission in Brazil (1994-2016): a time series modeling. Braz J Infect Dis 2019;23:218-23. [CrossRef]

6. Luzuriaga K. Mother-to-child transmission of HIV: a global perspective. Curr Infect Dis Rep 2007;9:511-7. [CrossRef]

7. Centers for Disease Control and Prevention (CDC). Achievements in public health. Reduction in perinatal transmission of HIV infection-United States, 1985-2005. MMWR Morb Mortal Wkly Rep
2006;55:592-7.

8. Esber A, Cohen S, Dempsey A, Cheever LW. Using systems of care and a public health approach to achieve zero perinatal HIV transmissions. JAMA Pediatr 2017;171:421-2. [CrossRef]

9. Evans C, Jones CE, Prendergast AJ. HIV-exposed, uninfected infants: new global challenges in the era of paediatric HIV elimination. Lancet Infect Dis 2016;16:e92-107. [CrossRef]

10. Newell ML, Brahmbhatt H, Ghys PD. Child mortality and HIV infection in Africa: a review. AIDS 2004;18 Suppl 2:S27-34. [CrossRef]

11. Chukwuemeka IK, Fatima MI, Ovavi ZK, Olukayode O. The impact of a HIV prevention of mother to child transmission program in a nigerian early infant diagnosis centre. Niger Med J 2014;55:204-8. [CrossRef]

12. Mandelbrot L, Tubiana R, Le Chenadec J, Dollfus C, Faye A, Pannier E, et al; ANRS-EPF Study Group. No perinatal HIV-1 transmission from women with effective antiretroviral therapy starting before conception. Clin Infect Dis 2015;61:1715-25. [CrossRef]

13. Sütçü M, Aktürk H, Somer A, Hançerli Törün S, İnce Z, Çoban A, et al. Mother-to-child transmisson of HIV: an eight-year experience. Mikrobiyol Bul 2015;49:542-53. [CrossRef]

14. İnkaya AÇ, Örgül G, Halis N, Alp Ş, Kara A, Özyüncü Ö, et al. Perinatal outcomes of twenty-five human immunodeficiency virus-infected pregnant women: Hacettepe University experience. J Turk Ger Gynecol Assoc 2020;21:180-6. [CrossRef]

15. Gülümser Ç, Erbaydar T. HIV/AIDS epidemic in Turkey and use of antiretroviral drugs for treating pregnant women and preventing HIV infection in infants. Turk J Obstet Gynecol 2015;12:192-8. [CrossRef]

16. Fernández-Ibieta M, Ramos Amador JT, Guillén Martín S, GonzálezTomé MI, Navarro Gómez M, Iglesias González-Nicolás E, et al. Why are HIV-infected infants still being born in Spain? [Article in Spanish]. An Pediatr (Barc) 2007;67:109-15. [CrossRef]

17. Townsend CL, Cortina-Borja M, Peckham CS, de Ruiter A, Lyall H, Tookey PA. Low rates of mother-to-child transmission of HIV following effective pregnancy interventions in the United Kingdom and Ireland, 2000-2006. AIDS 2008;22:973-81. [CrossRef]

18. Warszawski J, Tubiana R, Le Chenadec J, Blanche S, Teglas JP, Dollfus C, et al; ANRS French Perinatal Cohort. Mother-to-child HIV transmission despite antiretroviral therapy in the ANRS French Perinatal Cohort. AIDS 2008;22:289-99. [CrossRef]

19. Potty RS, Sinha A, Sethumadhavan R, Isac S, Washington R. Incidence, prevalence and associated factors of mother-to-child transmission of HIV, among children exposed to maternal HIV, in Belgaum district, Karnataka, India. BMC Public Health 2019;19:386. [CrossRef]

20. Okoko NA, Owuor KO, Kulzer JL, Owino GO, Ogolla IA, Wandera RW, et al. Factors associated with mother to child transmission of HIV despite overall low transmission rates in HIV-exposed infants in rural Kenya. Int J STD AIDS 2017;28:1215-23. [CrossRef]

21. Read JS, Samuel NM, Srijayanth P, Dharmarajan S, Van Hook HM, Jacob M, et al; PMTCT Project. Infants of human immunodeficiency virus type 1-infected women in rural south India: feeding patterns and risk of mother-to-child transmission. Pediatr Infect Dis J 2010;29:14-7. [CrossRef]

22. Mintsa-Ndong A, Ndong-Ella C, Boussougou RK, Busugu LM, Mba A, Agwambouet FA, et al. Mother-to-child HIV-transmission prevention programs in a sub-Saharan African setting: The Gabonese experience. Int J STD AIDS 2018;29:221-6. [CrossRef]

23. World Health Organization. Antiretroviral drugs for treating pregnant women and preventing HIV infection in infants: recommendations for a public health approach- 2010 version. Geneva, Switzerland: WHO; 2010. Available at: https://www.who.int/hiv/pub/mtct/an- 
tiretroviral2010/en/. Accessed Apr 21, 2021.

24. De Cock KM, Fowler MG, Mercier E, de Vincenzi I, Saba J, Hoff E, et al. Prevention of mother-to-child HIV transmission in resourcepoor countries: translating research into policy and practice. JAMA 2000;283:1175-82. [CrossRef]

25. Siegfried N, van der Merwe L, Brocklehurst P, Sint TT. Antiretrovirals for reducing the risk of mother-to-child transmission of HIV infection. Cochrane Database Syst Rev 2011:CD003510. [CrossRef]

26. Mugwaneza P, Lyambabaje A, Umubyeyi A, Humuza J, Tsague L, Mwanyumba F, et al. Impact of maternal ART on mother-to-child transmission (MTCT) of HIV at six weeks postpartum in Rwanda. BMC Public Health 2018;18:1248. [CrossRef]

27. Olakunde BO, Adeyinka DA, Olawepo JO, Pharr JR, Ozigbu CE, Wakdok S, et al. Towards the elimination of mother-to-child transmission of HIV in Nigeria: a health system perspective of the achievements and challenges. Int Health 2019;11:240-9. [CrossRef]

28. Hurst SA, Appelgren KE, Kourtis AP. Prevention of mother-to-child transmission of HIV type 1: the role of neonatal and infant prophylaxis. Expert Rev Anti Infect Ther 2015;13:169-81. [CrossRef]

29. Chappell CA, Cohn SE. Prevention of perinatal transmission of human immunodeficiency virus. Infect Dis Clin North Am 2014;28:529-47.

30. Yitayew YA, Bekele DM, Demissie BW, Menji ZA. Mother to child transmission of HIV and associated factors among HIV exposed infants at public health facilities, Dessie Town, Ethiopia. HIV AIDS (Auckl) 2019;11:343-50. [CrossRef]

31. Lumaca A, Galli L, de Martino M, Chiappini E. Paediatric HIV-1 infection: updated strategies of prevention mother-to-child transmission. J Chemother 2018;30:193-202. [CrossRef]

32. Teasdale CA, Marais BJ, Abrams EJ. HIV: prevention of mother-tochild transmission. BMJ Clin Evid 2011;2011:0909. 